10

3

6

This is the final accepted version of the article Thomas Oliver Mérö, László Lontay, Szabolcs Lengyel (2015) Habitat management varying in space and time: the effects of grazing and fire management on marshland birds. Journal of Ornithology, Volume 156, Issue 3, pp 579-590. (DOI: 10.1007/s10336-015-1202-9).

The final published version can be found at http://link.springer.com/article/10.1007\%2Fs10336-015-1202-9

\title{
Habitat management varying in space and time: the effects of grazing and fire
}

management on marshland birds

${ }^{1}$ Department of Ecology, Faculty of Science and Technology, University of Debrecen, Egyetem tér 1, H-4032 Debrecen, Hungary, e-mail: thomas.oliver.mero@gmail.com

${ }^{2}$ Aggtelek National Park Directorate, Tengerszem oldal 1, H-3758 Jósvafö, Hungary, e-mail: bodrogzug@gmail.com

3 Department of Tisza River Research, Danube Research Institute, Centre for Ecological Research, Hungarian Academy of Sciences, Bem tér 18/c, H-4026 Debrecen, Hungary, e-mail: lengyel.szabolcs@okologia.mta.hu

Corresponding author Thomas Oliver MÉRÖ, Department of Ecology, University of Debrecen, Egyetem tér 1, Debrecen, 4032, Hungary, e-mail: thomas.oliver.mero@gmail.com, telephone: +36 (52) 512-900 / 62349, fax: +36 (52) 512-941 
26 Abstract Freshwater wetlands and marshes with extensive reedbeds are important hotspots of

27 biological diversity but are subject to biotic homogenisation in the absence of proper

28 management. We assessed the impact of spatiotemporally variable management by cattle grazing

29 (for four years) and late-summer burning (one or three years before the study) on both songbirds

30 and non-passerines in a previously homogeneous reedbed. We surveyed birds by a combination

31 of line transects and point counts in a quasi-experimental design consisting of six treatment

32 levels. Management led to a higher diversity of marsh habitats and increased bird diversity. The

33 species richness and abundance of non-passerines (ducks and geese, wading birds, gulls and

34 terns, rails, coots and grebes) was higher in recently burned than in unburned or old-burned

35 patches. The species richness of farmland songbirds was higher in grazed patches than in non-

36 grazed patches, and reed songbirds had higher richness and abundance in unburned, old-burned

37 or grazed patches than in recently burned patches. Total Shannon diversity and evenness of birds

38 was lowest whereas Simpson diversity was highest in the most intensive treatment (patches

39 grazed and twice-burned). Non-managed patches had fewer species and individuals of all groups

40 except reed songbirds. The proportion of old reed was low in recently burned and grazed patches

41 and similarly high in all other treatments. No other property of reed stands was influenced by

42 management, and both the allocation and the effect of management were independent from water

43 level. Spatiotemporally variable management by cattle grazing and late-summer burning may

44 thus simultaneously benefit several groups of birds. The effect of burning alone disappeared in

45 three years even in the presence of grazing, thus, it needs to be repeated every 2-3 years. We

46 conclude that both management actions are necessary to establish and maintain a high diversity

47 of habitats for marshland bird communities. 
49 Keywords $\cdot$ habitat diversity $\cdot$ habitat heterogeneity $\cdot$ Hortobágy National Park $\cdot$ intermediate 50 disturbance hypothesis $\cdot$ mosaic vegetation salt marsh

51 
54 Habitat management for biodiversity conservation relies on two main principles, the species-area 55 relationship (SAR) and the intermediate disturbance hypothesis (IDH, Connell 1978). According 56 to the SAR, the number of species generally increases with area (Connor and McCoy 2001; Pan 57 2013), thus, management of larger habitat patches should conserve more species. However, the relationship between the area and number of species is not linear; initially the increment of the

59 species is fast, but becomes slower as area increases (Báldi and Kisbenedek 2000; Celada and 60 Bogliani 1993; Paracuellos and Tellería 2004). According to the IDH, species diversity is 61 maximized when ecological disturbance is at intermediate levels (McCabe and Gotelli 2000; 62 Schwilk et al. 1997). At low levels of disturbance, the diversity of species often decreases due to 63 biotic homogenization (Lockwood and McKinney 2001). For example, in reed habitats, the 64 characteristics and physiognomic structure of habitats becomes homogeneous in the absence of 65 disturbance by mowing, cutting, flooding, or burning, at both the local and landscape scales 66 (Lougheed et al. 2008). Under appropriate long-term management, the homogeneous structure of 67 the reed habitat breaks up and a more heterogeneous structure is formed, which provides more 68 suitable habitats for a wider spectrum of species through complexity in vegetation structure, and 69 composition, density and biomass (Wiens 1997; Christensen 1997).

71 Freshwater wetlands are of outstanding importance for biodiversity and have become a priority 72 in conservation (Bobbink et al. 2006; Schweiger et al. 2002). Wetlands have decreased 73 considerably in size, number and quality in the last century in Europe (and in Hungary, 74 Vásárhelyi 1995). Although wetlands have been subject to intensive research in conservation and 
75 restoration (Wagner et al. 2008; Wheeler et al. 1995), little is known about the appropriate

76 spatiotemporal allocation and impact of reedbed management in wetlands (Ausden et al. 2005).

77 The theory of adaptive ecosystem management has been present since the 1980s, but areas

78 available for management are rarely large enough to accommodate and experiment with different

79 management regimes (Groom et al. 2006). In temperate grasslands, spatiotemporally variable

80 management by prescribed fire and by grazing resulted in highly heterogeneous habitats

81 (Fuhlendorf and Engle 2001; Hartnett et al. 1996; Vinton et al. 1993). In most wetland studies,

82 sampling areas are too small (under $1 \mathrm{ha}$ ) to evaluate the effects of disturbance or the undisturbed

83 operation of natural ecological processes on higher taxonomic groups (Wagner et al. 2008). In

84 addition, most studies followed up only one management action and focused on invertebrates

85 (Ausden et al. 2005; Ditlhogo et al. 1992; Schmidt et al. 2005; Hardman et al. 2012). As a result,

86 we generally know little on how spatiotemporally variable management affects vertebrates,

87 habitats and ecological processes.

89 The management of reedbeds includes various actions such as periodical flooding ( Poulin et al. 90 2002; Graveland 1998), mowing or cutting (harvesting, Poulin and Lefebvre 2002; Vadász et al.

91 2008), burning (Moga et al. 2010), grazing/trampling, excavating and herbicide application, or

92 their combination (e.g. burning and cutting in Báldi and Moskát 1995). While effects such as

93 grazing, change in water level, and burning may be considered threats under uncontrolled

94 conditions, they can be important conservation measures as part of a management strategy

95 aiming to apply these effects as controlled disturbances (Margoluis et al. 2009; Salafsky et al.

96 2009). A meta-analysis of 21 European studies on the effect of reed management by Valkama et

97 al. (2008) found that management by harvesting, burning, mowing and grazing alters the 
structure of reedbeds, with reed stems becoming shorter and denser in managed sites compared to non-managed ones. Plant species richness usually increases by management but invertebrate richness decreases after 1-2 years of management. In birds, the abundance of passerine species decreases on average by $60 \%$ after burning and reed harvesting (Valkama et al. 2008). Many reedbed-breeding passerines, mainly Acrocephalus warblers, actively avoid cut areas, while others show decreased abundance and diversity (Vadász et al. 2008; Poulin and Lefebvre 2002). Some reed songbirds, however, use managed areas, for example, the Aquatic Warbler ( $A$. paludicola) prefers cut reed stands (Tanneberger et al. 2009), while the Stonechat (Saxicola torquatus) and Marsh Warbler (A. palustris) prefer burned reed (Moga et al. 2010). We know much less on how reed management influences non-passerine birds. In addition, little is known on whether there are interactive or synergistic effects of two different management actions on birds (Valkama et al. 2008) to maximize their diversity and abundance in reedbeds.

The aim of this study was to evaluate the impact of spatiotemporally variable management by grazing and burning on marshland bird communities and functional groups. We addressed the following questions: (1) Do the responses of the bird community or functional groups to management differ by the type or regime of management? (2) Do the responses differ among bird functional groups including both passerines and non-passerines? (3) Is there interaction or synergy between the impacts of management by grazing and management by burning? To answer these questions, we apply a quasi-experimental approach in which experimental units (line transects combined with point counts) were replicated in similarly managed areas along a gradient of no management, one treatment (grazing), or two treatments (grazing and burning). 


\section{Methods}

122

123 Management actions

124

125 The study was conducted at the Fekete-rét marsh (600 ha; N 47.559 ${ }^{\circ}$, E $\left.20.932^{\circ}\right)$, the largest

126 marsh in the Egyek-Pusztakócs marsh system (Hungary). In order to open up reedbeds, control

127 reed and increase the diversity of habitats by re-creating the former wetland mosaic, two

128 management actions were designed in 2004: grazing/trampling by cattle and fire management

129 (prescribed burning).

130

131 Grazing - Grazing by Hungarian grey cattle was started in spring 2006. Trampling on rhizomes

132 through controlled grazing has little effect on reed density but long term grazing reduces the

133 vigour of the reed plant considerably (Cross and Fleming 1989). Grey cattle are highly suitable

134 for grazing in marshes as they will go after and consume reed even in deep water, up to $1.5 \mathrm{~m}$

135 (Kelemen 2002). Grazing was conducted by a stock of 180 grey cattle between late April and

136 late November every year between 2006 and 2009. Cattle were free to roam in the entire

137 southern half of the marsh (c. 300 ha) to mimic natural disturbance as closely as possible.

138 However, grazing was concentrated in the SW part of the marsh (c. 200 ha) closest to the fold

139 (Figure 1, Figure S1) and cattle also used meadows and grasslands (total c. 100 ha) surrounding

140 the marsh. This resulted in a gradient of grazing intensity from heavily grazed/trampled through

141 slightly grazed/trampled to ungrazed areas.

142 
143 Fire management - Burning took place in early September in both 2007 and 2009, in the non144 breeding period. The late summer is the flowering period of reed (late summer), when most 145 nutrients are in the shoot/inflorescence of the plant, reed can be controlled effectively through 146 burning due to damage on the nutrient-poor rhizomes (Cross and Fleming 1989). Fire 147 management was designed and implemented in cooperation with professional fire crews. In 148 2007, the fire was started on the E side of the marsh and progressed westwards, whereas in 2009, 149 the fire progressed from W to E with westerly winds. Although fire intensity varied, as suggested 150 by flames of different height (generally 2-3 m but sometimes up to 10-12 m), both fires caused a 151 near-total loss of old and green reed (Figure S2). The total area burned was 110 ha in 2007 and 152130 ha in 2009. Although some areas were burned in only one year, there was also a substantial 153 area that was burned in both years (Figure 1).

155 Both management actions were considered as ecological disturbances, which can be 156 characterised by their regime (duration, size, intensity, frequency, reversibility etc.) (Salafsky et 157 al. 2009; Salafsky et al. 2008). By allocating two treatment levels of grazing management and 158 three levels of burning, our experiment involved variability in the duration (grazed never vs. for 159 four years), the frequency (burned never, once, or twice in four years) and the intensity (the 160 intensity of grazing and burning were allowed to vary within the marsh as described above) of 161 disturbance.

163 Experimental design and data collection 
165 The experimental design consisted of an incomplete crossing of the grazing and burning

166

167

168

169

170

171

172 173 actions (treatment levels, Table 1).

174

175

176 177 the restriction that transects were at least $100 \mathrm{~m}$ apart from each other. The orientation of 178

179

180

181

182

183

184 185

186

187 management with six treatment levels (Table 1). Both cattle and fires were free to roam in the southern half of the marsh to mimic ancient disturbances as close as possible, which resulted in managed areas of irregular shapes. We digitized the areas actually grazed and burned in detailed ground surveys at the end of the vegetation period. We recorded point localities using a handheld GPS receiver during walking along the visually identified borderline of regularly grazed/trampled and un-grazed marsh and burned and unburned reed. A spatial overlay of the obtained polygons allowed us to identify areas with six different combinations of management

In each of the six treatment levels, we designated five 100-m-long transects as replicates (total $\mathrm{n}=30$ ). The transect starting points were selected randomly within similarly treated areas with transects was selected randomly, except where the shape of the treated area restricted the orientation. We walked transects once in April and once in May in 2010 to maximize the chances of recording both early-nesting and late-nesting species. Data from the two occasions were pooled per transect for analysis. We counted birds for 5 min each at $0,25,50,75$ and $100 \mathrm{~m}$ from the starting point of the transect and also counted birds when walking between the points (combination of point counts and the line transect method, Bibby et al. 2000; Gibbons and Gregory 2006; Gregory et al. 2004). We recorded all birds seen or heard but analysed only those that were within $25 \mathrm{~m}$ on both sides of transects. To avoid double-counting of the singing males of reed-nesting passerines we mapped their territories. Bird species were classified into functional groups based on their foraging and nesting characteristics (Perrins and Cramp 1998). 
189 We measured water depth at each of the five counting points, which were averaged for each

190 transect. We also quantified reed density and complexity at the three internal counting points to 191 characterize the effect of management. The number of old and new reed stems were counted in a 192 circle (diameter $40 \mathrm{~cm}$ ) positioned at a height of $1 \mathrm{~m}$ and $1 \mathrm{~m}$ in a randomly selected direction 193 from each internal counting point. We first estimated reed density (based on the counting at the 194 three internal points) by (i) the average number of old stems, (ii) the average number of new 195 stems, (iii) the total number of both old and new stems, and (iv) the average of total number of 196 stems, and $(\mathrm{v})$ the proportion of old reed stems (per total number of stems in the transect) 197 because old reed is important for the breeding of early reed-nesting passerines. Second, we 198 estimated reed complexity by (i) the standard deviation (SD) of the mean number of all stems 199 and (ii) the coefficient of variation (CV) in the number of all stems (standard deviation per mean 200 of number of all stems) for each transect. We also recorded two variables that potentially reflect 201 management, (i) the proportion of reed cover (1 for transects with a continuous cover of reed, 0.9 202 for transects with reed cover on $90 \mathrm{~m}$ etc.), and (ii) the proportion of the length of the transect 203 where reed had been cut relative to the total length of the transect (e.g. 0.2 indicating that reed 204 was cut on $20 \%$ of the 100 -m length). Evidence of reed cutting was found in eight transects or $20527 \%$ of $n=30$ transects. We thus obtained five variables for reed density (mean number of old 206 and new stems, total number of all stems, mean number of stems, proportion of old stems), two 207 variables for reed complexity (SD of the mean number of all stems and CV in the number of all 208 stems), and two additional variables potentially reflecting management effects: reed cover, 209 proportion of transect length cut in each transect. We thus estimated nine variables for reedbed 
210 structure to allow for the possibility that responses of bird functional groups will differ by the

211 preference of birds to different aspects of reed.

213 Statistical analysis

215 We used General Linear Models (GLM) to model the responses of the bird assemblage to the 216 management treatment and various covariates. Response variables in GLMs were species 217 richness, total abundance, Shannon-Wiener and Simpson diversity and evenness for all birds and 218 species richness and abundance for bird functional groups. Independent variables were 219 management, nine variables of reedbed structure, and water depth. Because there was 220 collinearity among the seven variables describing reed density and complexity (Pearson 221 correlations, $\mathrm{r}>0.53, \mathrm{p}<0.01$ ), we only considered those three combinations of variables which 222 were not correlated (number of old reed stems with S.D. of reed density; number of new reed 223 stems with C.V. of reed density; and proportion of old reed stems with S.D. of reed density). The 224 proportion of reed cover or proportion of reed cut were not related to the reed density or 225 complexity variables, therefore, we entered these variables in all full models. Finally, there was 226 no difference in water depth among the areas with different management actions (one-way 227 ANOVA, $\mathrm{F}_{5}=0.434, \mathrm{p}=0.821$ ). Furthermore, there was no significant correlation between 228 water depth and either of the nine variables describing reedbed structure (Spearman correlations, $\left.2290.171<\mathrm{r}_{\mathrm{s}}<0.224, \mathrm{p}>0.230\right)$.

230

231 We first ran GLMs to select models that best described our data relative to the three 232 combinations of reed density and complexity variables. We used Akaike's Information Criterion 
233 to select the best of the three models for each response variable. In the second step, we ran the

234 best-fitting full models and applied a backward stepwise algorithm to remove non-significant 235 variables and interaction terms. The final reduced models were then fitted to estimate 236 coefficients and compare means.

237

238 The normality of variables was checked by the Shapiro-Wilk test and the homogeneity of 239 variances was checked by Bartlett tests. One-way ANOVA was used if the assumptions of 240 parametric tests were met, in other cases, we used Kruskal-Wallis tests to analyse the differences 241 between the six treatments. We used the R environment 2.15.2 and SPSS 17.0 for statistical 242 analyses.

244 Results

245

246 We recorded 1063 individuals of 45 bird species (Table S1). The number of species breeding in 247 the marsh or the surrounding area was $39(\mathrm{n}=965$ individuals $)$, whereas migrants included 6 248 species $(\mathrm{n}=98$ individuals). The mean number of individuals per transect was $35.4 \pm 20.17$.

250 Effects of management on the bird community

251

252 The Shannon and Simpson diversity as well as the evenness of bird communities were 253 significantly affected by management, whereas total species richness and abundance were not 254 (Table 2, Figure 2). Shannon diversity and evenness were low in grazed patches burned twice 255 and were uniformly high in all other treatments (Figure 2C, E), whereas Simpson diversity was 
256 highest in grazed patches burned twice and lower in all other treatments (Figure 2D). Species

257 richness was not affected by any of the factors studied, although the effect of reed complexity

258 was marginally non-significant (Table 2). Abundance appeared to be higher in grazed patches

259 with recent burning (burned in 2009 and burned twice), although large variation did not result in

260 statistically significant differences among treatments (Figure 2B). Rather, bird abundance was

261 negatively affected both by reed cover and water depth (Table 2), indicating more birds in

262 transects with more open water and with shallower water.

263

264 Effects of management on bird groups

265

266 The response of birds to management varied greatly in different groups (Figure 3, Table S2).

267 Ducks and geese had higher abundance in grazed newly-burned patches, followed by grazed

268 twice-burned and grazed unburned patches (Figure 3B). There was no difference in species

269 richness by treatment (Figure 3A). Wading birds as well as gulls and terns showed a similar

270 pattern but both their species richness and abundance were significantly higher in newly-burned

271 patches than in other treatments (Figure 3C-F). Reed songbirds showed a contrasting pattern in

272 that both their species richness and abundance were lowest in newly-burned patches and were

273 significantly higher in old-burned or unburned patches (Figure 3G, H). The species richness of

274 farmland songbirds was higher in grazed patches with new burning than in non-grazed patches

275 and was intermediate in other grazed patches regardless of whether patches were burned or not

276 (Figure 4I), indicating the overall importance of grazing for farmland birds. Finally, the species

277 richness of rails, coots and grebes was influenced positively by reed complexity (CV) and water

278 depth and negatively by reed cover but not by management per se (Table S2). 
Management effects on reed

282 The proportion of old reed differed significantly between the six treatments (Kruskal-Wallis test, $\left.283 \chi_{5}^{2}=18.683, \mathrm{p}=0.0022\right)$, because newly and twice-burned areas combined with grazing had 284 little old reed, whereas other treatments had at least $35 \%$ on average (Figure 4 ). Furthermore, the 285 proportion of old reed was higher in non-managed than in grazed unburned patches, whereas 286 there was no such difference by grazing between the two old-burned treatment levels (Figure 4). 287 Finally, there was no difference among treatment levels in either mean reed density (one-way 288 ANOVA, $\left.F_{5}=1.77, p=0.156\right)$, reed complexity $\left(S D: F_{5}=1.02, p=0.425 ; C V: F_{5}=1.30, p=\right.$ $0.297)$ or reed cover $\left(\chi_{5}^{2}=3.748, \mathrm{p}=0.586\right)$.

\section{Discussion}

294 We found that spatiotemporally variable management by grazing and burning led to a more 295 heterogeneous landscape structure of marsh habitats (Figure S1), which increased bird diversity 296 in three main ways. First, there were more species and individuals of non-passerines in recently 297 burned patches than in unburned or old-burned patches. Second, there were more species and 298 individuals of reed songbirds in unburned, old-burned or grazed patches than in newly-burned 299 patches. Finally, there were more species of farmland birds in grazed patches, particularly in 300 newly-burned ones, than in non-grazed patches. Our results thus indicate that spatiotemporally 301 variable management may simultaneously benefit several functional groups of birds. Our 
302 findings also suggest that this benefit was mediated by management-caused changes in reed

303 structure and increases in habitat diversity and was independent of the variation in water level,

304 which further reinforces the importance of management by grazing and burning.

305

306 Effects of cattle grazing

307 Continuous grazing through four vegetation periods led to the establishment of trampled 308 corridors and areas in the homogeneous reed, where old reed stems were partially destroyed and 309 the growth of new reed was stunted. Grazing by cattle has been known to efficiently control reed 310 (van Deursen and Drost 1990), although its effect depends on the type of livestock and grazing 311 intensity (Vulink et al. 2000) and the duration of grazing (Korner 2013). In our study, grazing 312 and trampling led to a mosaic-like patch structure of habitats, which was preferred by farmland 313 birds and several reed songbirds. Although the number of wading birds and waterfowl also 314 increased in a long-term grazing programme at Lake Neusiedler in eastern Austria (Korner 315 2013), we did not find such a tendency. In our study, wading birds and waterfowl preferred 316 partially flooded areas with both grazing and burning, showing that grazing alone was not 317 enough to create potential breeding, feeding or roosting habitats for these bird groups.

319 For most reed songbirds, patches with a high proportion of old reed were preferable as their 320 species richness and abundance was high relative to patches that were recently burned. The non321 managed reed was characterized by high reed songbird diversity and evenness compared to 322 managed stands, similarly to the findings in Valkama et al. (2008). For example, Báldi and 323 Moskát (1995) compared species richness and abundance of reed passerines among cut, burned, 324 non-managed reed and heterogeneous reed containing bulrush, meadows and trees. The 
325 abundance and species richness of reed passerines, a group which encompassed both reed and

326 farmland songbirds in our study, was significantly higher in the control area than in managed or

327 heterogeneous areas. Báldi and Moskát (1995) concluded that homogeneous reed stands were

328 highly suitable for reed passerines, thus, they suggested limited or no management for reed

329 passerines. Most other studies focusing on reed passerines also found higher diversity in

330 homogeneous and unmanaged reed (Vadász et al. 2008; Graveland 1999). In several studies, the 331 area-sensitive reed passerines positively preferred non-managed but heterogeneous reed beds

332 (Báldi and Kisbenedek 1998; Báldi 2004; Benassi et al. 2009). However, some authors reported 333 that reed songbirds may differ in their preferences with regard to management (Poulin and 334 Lefebvre 2002) or to water depth because some species nest exclusively in flooded non-managed 335 reedbeds, while others have a wider tolerance regarding the absence of water (Neto 2006).

\section{Effects of burning}

338 The late-summer burning of reed resulted in shallow pools with low vegetation cover in the next 339 year, which was attractive to waterfowl and wading birds. This effect largely disappeared 340 because reed grew back strong in these areas by year 3 after burning, resulting in no difference 341 between old-burned and non-burned patches for the non-passerine groups. Our results thus 342 suggest that burning is highly effective at controlling reed but that this effect is temporary at 343 most. These results suggest that burning needs to be repeated every 2-3 years to reap its full 344 benefits to non-passerine birds. In contrast, the species richness of passerines in (Moga et al. 345 2010) was higher in burned areas. However, in Moga et al. (2010) and other studies (e.g. Mérő et 346 al. 2014) reed was burned in March of the year of the survey. To our knowledge, our study is the 347 first to report the next-year effects of late-summer burning of reedbeds. 
349 We found that the proportion of old reed was significantly lower in the two recently burned and 350 grazed patches than in the other four treatment levels. Experimental studies of spring burning 351 and mowing of reed resulted in extensive damage to the shoots and differences in reed stem

352 density and diameter; the reed compensate damages on young shoots due to spring burning by 353 the growth of several thinner replacement shoots (van der Toorn and Mook 1982). Van Deursen 354 and Drost (1990) found that reed stands might thus be in equilibrium with grazing pressure, but 355 also reported that reed production can be reduced to $40 \%$ due to grazing compared to an 356 ungrazed stand. In the spring the following year we still detected the effect of late-summer 357 burning, furthermore, trampling by cattle in the burned areas throughout the autumn represented 358 further damage to the reed plants which led to decreased reed productivity in spring. Our results 359 thus suggest that the combination of burning and grazing leads to long-lasting damage to reed 360 plants in areas burned in late summer, where non-passerines and farmland songbirds showed 361 high richness and abundance the next spring.

363 Water depth

364 Besides management and reed properties, water depth also significantly influenced the bird 365 community (in four of the five models) and some functional groups. There were positive 366 relationships between water depth and Shannon diversity and evenness, and the species richness 367 of reed songbirds, and rails, coots and grebes, and there were negative relationships between 368 water depth and total abundance, Simpson diversity, the abundance of gulls and terns, and the 369 species richness of farmland songbirds. These results are in line with expectations based on the 370 general vegetation patterns largely determined by water depth and on the feeding and habitat use 
371 properties of the functional groups involved. For example, shallow water is more likely to host a

372 diverse vegetation (bulrushes, Schoenoplectus spp., Typha spp., grasses e.g. Alopecurus,

373 Beckmannia), which gradually gives way to more homogeneous reedbeds in waters of

374 intermediate depth, whereas very deep water will usually be open water devoid of emergent

375 vegetation but rich in floating or submerged vegetation (pondweed, e.g. Potamogeton spp.,

376 Lemna spp., Ceratophyllum spp. etc.). The positive relationship between water depth and the

377 richness of reed songbirds and rails, coots and grebes can be explained that transects going

378 through intermediate water depth likely provided better conditions for nesting and feeding for

379 reed songbirds (mainly Acrocephalus spp., plus Emberiza schoeniclus, Locustella luscinioides,

380 Luscinia svecica, Motacilla flava, Panurus biarmicus) and rails, coots and grebes (Fulica atra,

381 Porzana parva, Rallus aquaticus, Tachybaptus ruficollis) than transects in shallower water. The

382 somewhat surprising negative relationship between water depth and gull/tern abundance was

383 because gulls and terns, which usually nest on floating vegetation in open water, often rested in 384 cattle-trampled openings in shallow water or because shallower water probably provided better 385 conditions for feeding. Finally, the negative relationship between water depth and species

386 richness of farmland songbirds conformed to the expectations because habitats typically required 387 by these species (Alauda arvensis, Hirundo rustica, Miliaria calandra, Saxicola rubetra, Corvus 388 cornix) became rarer with increasing water depth.

390 Despite the influence of water depth on several response variables, in the transects surveyed, 391 there was no systematic variation in water depth among the different treatments, and there were 392 no relationships between water depth and reed structure variables. Moreover, there was no 393 interaction between management and water depth in any of the models. These findings indicated 
394 that the effects of management and water depth were independent from one another. These 395 observations, however, also suggest that varying the water level as part of a long-term marsh 396 management programme can be promising as an introduction of further disturbance to increase 397 the diversity of marsh habitats and to benefit a variety of bird species. For example, many 398 species such as ducks and geese, storks and herons, and coots and grebes require a minimum of 399 water for nesting and feeding (Nummi et al. 2013; Pöysa and Vaananen 2014; Causarano and 400 Battisti 2009). Beyond the pure presence of water, the changes in the water level can also affect 401 the presence and abundance of these and several other groups of water birds (e.g. Causarano et 402 al. 2009; Redolfi De Zan et al. 2010; Zacchei et al. 2011).

404 Management and the intermediate disturbance hypothesis

405 The results of spatiotemporally variable, combined management by burning and grazing fit the 406 expectations based on IDH in the study marsh. First, the IDH predicts that high disturbance will 407 lead to lower diversity because fewer species will tolerate intense or too frequent disturbance. 408 Our results support this prediction because total Shannon diversity and evenness were lowest 409 whereas Simpson diversity was highest for the patches with highest disturbance (grazed and 410 twice-burned). Because Shannon diversity is more affected by rare species while Simpson 411 diversity is more affected by common species (Magurran 2004), this result suggests that patches 412 with highest disturbance had disproportionately more of the common rather than the rare species.

413 Second, the IDH predicts that low disturbance will be tolerated by a few species, leading to 414 biotic homogenization. The finding that control (non-managed) patches had fewer species and 415 individuals of all groups but reed songbirds appears to support this prediction because reed 
416 songbirds avoided combined, burned and grazed patches. However, because reed songbirds had

417 many species, this pattern did not show for total diversity.

419 Conclusions

420 We conclude that spatiotemporally variable combined management of reedbeds by grazing and 421 burning positively affects the bird community. Grazing and trampling by cattle led to the 422 opening up of homogeneous reedbeds, creating habitat patches preferred by farmland songbirds.

423 Late-summer burning followed by autumn grazing was effective in controlling reed so that 424 habitats suitable for several non-passerine groups (waterfowl, wading birds, gulls and terns) were 425 established. Reed control led to the increase of open water surfaces with patchy reed, a habitat 426 preferred by rails, coots and grebes. Finally, non-managed patches had high proportions of old 427 reed, which provided habitat for reed songbirds. Many of these changes were mediated by the 428 availability or proportion of old reed, which was the property of reed most affected by 429 management. The spatiotemporally variable management thus led to an increased diversity of 430 habitats and a more heterogeneous marsh landscape, which was reflected in the increased 431 richness and abundance of bird functional groups.

433 Practical implications

434 Wetland managers are often faced with the choice of the hierarchical levels (populations/species 435 or the entire community) they target with conservation actions. When the goal of conservation 436 actions is to increase the density of area-sensitive and specialised bird species (e.g. Acrocephalus 437 scirpaceus, Ixobrychus minutus), then the population/species level is targeted (Benassi et al. 438 2009). In contrast, when the goal is to increase the number of species, managers target the 
439

440

441

442

443

444

445 446 habitat requirements of specialists.

447

448

449

450

451

452

453

454

455

456

457

458

459

460

461

\section{Acknowledgements}

community level and use richness and diversity indices (Magurran and McGill 2011) for followup (e.g. Rácz et al. 2013; Déri et al. 2011). Reedbed management has to be prioritised based on the local conservation needs and managers need to consider the trade-off between increasing the size of homogeneous reed stands for reedbed specialist species on one hand and increasing the diversity of habitats by grazing, burning or water level management on the other. The exceptionally large spatial scales available for our experiment made it possible to provide an example for management to benefit the entire avian community without compromising the

Our study provided several other practical implications. Grazing by cattle needs to be continuous and maintained over several years to keep the reedbed loose and heterogeneous. Late-summer burning can also efficiently control reed but burning in itself causes only a temporary effect that disappears in three years even in the presence of grazing, thus, it needs to be repeated every two or three years. Ideally, both actions should be carried out in the non-breeding period of birds or the inactive period of other animals of conservation importance. The late summer, after breeding ceases and before migration or wintering begins, offers a good time period. Trampling in burned areas in the autumn and early spring by cattle leads to the establishment of shallow banks with little or no vegetation, which is attractive for waterfowl, wading birds and gulls and terns. Generally we conclude that both management actions, grazing and burning, are needed to maintain a high diversity of habitats for marshland bird communities. 
463 We thank Hortobágy National Park for supporting the study. Large-scale habitat management 464 was conducted in an EU LIFE-Nature project (LIFE04NAT/HU/000114, life2004.hnp.hu, 465 Lengyel et al. 2012). The study was funded by three grants from the National Scientific Research 466 Fund of Hungary (OTKA NNF 78887, NNF 85562, K 106133) to SL. We thank C. Battisti, T. 467 Gottschalk and an anonymous reviewer for helpful comments on earlier versions of the 468 manuscript.

Conflict of interest The authors declare that they have no conflict of interest.

\section{Supplementary Material}

473 Additional Supplementary Material may be found in the online version of this article:

474 Supplementary Material Methods: Management needs: previous history, Figure S1

475 Supplementary Material Results: Table S1, Table S2, Figure S2

\section{References}

478

479

480

481

482

483

484

485

486

487

488

489

490
Ausden M, Hall M, Pearson P, Strudwick T (2005) The effects of cattle grazing on tall-herb fen vegetation and molluscs. Biological Conservation 122:317-326

Báldi A (2004) Area requirements of passerine birds in the reed archipelago of Lake Velence. Acta Zoologica Academiae Scientiarum Hungaricae 50:1-8

Báldi A, Kisbenedek T (1998) Factors influencing the occurrence of Great-White Egret (Egretta alba), Mallard (Anas platyrhynchos), Marsh Harrier (Circus aeroginosus), and Coot (Fulica atra) in the reed archipelago of Lake Velence, Hungary. Ekológia (Bratislava) 17:384-390

Báldi A, Kisbenedek T (2000) Bird species number in an archipelago of reeds at Lake Velence, Hungary. Global Ecology and Biogeography 9:451-461

Báldi A, Moskát C (1995) Effect of reed burning and cutting on breeding birds. Paper presented at the Integrating People and Wildlife for a Sustainable Future. Proceedings of the First International Wildlife Management Congress, Bethesda, Maryland, 
Benassi G, Battisti C, Luiselli L, Boitani L (2009) Area-sensitivity of three reed bed bird species breeding in Mediterranean marshland fragments. Wetland Ecology and Management $17: 555-564$

Bibby CJ, Burgess ND, Hill DA, Mustoe SH (2000) Bird Census Techniques, 2nd ed. Academic Press, London

Bobbink R, Beltman B, Verhoeven JTA, Whigham DF (2006) Wetlands: Functioning, Biodiversity Conservation and Restoration. Springer, Berlin

Causarano F, Battisti C (2009) Effect of seasonal water level decrease on a sensitive bird assemblage in a Mediterranean wetland. Rendiconti Lincei 20:211-218

Causarano F, Battisti C, Sorace A (2009) Effect of winter water stress on the breeding bird assemblages of a remnant wetland in Central Italy. Revue d'Écologia (Terre Vie) 64:6172

Celada C, Bogliani G (1993) Breeding bird communities in fragmented wetlands. Bollettino di Zoologia 60:73-80

Christensen NL (1997) Managing for heterogeneity and complexity on dynamic landscapes. In: Pickett STA, Ostfeld RS, Shachak M, Likens GE (eds) The Ecological Basis for Conservation: Heterogeneity, Ecosystems, and Biodiversity. Chapman \& Hall, New York, pp 167-186

Connell JH (1978) Diversity in tropical rain forests and coral reefs: high diversity of trees and corals is maintained only in a non-equilibrium state. Science 199 (4335):1302-1310

Connor EF, McCoy ED (2001) Species-area relationships. In: Levin SA (ed) Encyclopedia of Biodiversity, vol 5. Academic Press, London, pp 397-411

Cross DH, Fleming KL (1989) Control of Phragmites or Common Reed. In: Cross DH, Wohs P (eds) Waterfowl Management Handbook. U.S. Fish and Wildlife Service, Fort Collins, pp $1-5$

Déri E, Magura T, Horváth R, Kisfali M, Ruff G, Lengyel S, Tóthmérész B (2011) Measuring the short-term success of grassland restoration: the use of habitat affinity indices in ecological restoration. Restoration Ecology 19:520-528

Ditlhogo MKM, James R, Laurence BR, Sutherland WJ (1992) The effects of conservation management of reed beds. I. The invertebrates. Journal of Applied Ecology 29:265-276

Fuhlendorf SD, Engle DM (2001) Restoring heterogeneity on rangelands: ecosystem management based on evolutionary grazing patterns. BioScience 51:625-632

Gibbons DW, Gregory RD (2006) Birds. In: Sutherland WJ (ed) Ecological Census Techniques (second edition). Cambridge University Press, Cambridge, pp 308-344

Graveland J (1998) Reed die-back, water level management and decline of the Great Reed Warbler Acrocephalus arundinaceus in the Netherlands. Ardea 86:187-201

Graveland J (1999) Effects of reed cutting on density and breeding success of Reed Warbler Acrocephalus scirpaceus and Sedge Warbler A. schoenobaenus. Journal of Avian Biology 30:469-482

Gregory RD, Gibbons DW, Donald PF (2004) Bird census and survey techniques. In: Sutherland WJ, Newton I, Green RE (eds) Bird Ecology and Conservation. Oxford University Press, Oxford, pp 35-40

Groom MJ, Meffe GK, Carroll CR (2006) Principles of Conservation Biology. Sinauer Associates, Sunderland

Hardman CJ, Harris DB, Sears J, Droy N (2012) Habitat associations of invertebrates in reedbeds, with implications for management. Aquatic Conservation 22:813-826 
Hartnett DC, Hickman KR, Fischer WLE (1996) Effects of bison grazing, fire, and topography on floristic diversity in tallgrass prairie. Journal of Range Management 49:413-420

Kelemen J (2002) Legeltetés (Grazing). In: Ángyán J, Tardy J, Vajnáné Madarassy A (eds) Védett és érzékeny természeti területek mezőgazdálkodásának alapjai (Fundamentals of agriculture on protected and sensitive natural areas). Mezőgazda Kiadó, Budapest, pp 380-394

Korner I (2013) Long term monitoring of grazing in salt habitats on the eastern shore of Lake Neusiedl. Paper presented at the Conference Volume, 5th Symposium for Research in Protected Areas, Mittersill,

Lengyel S, Varga K, Kosztyi B, Lontay L, Déri E, Török P, Tóthmérész B (2012) Grassland restoration to conserve landscape-level biodiversity: a synthesis of early results from a large-scale project. Applied Vegetation Science 15:264-276

Lockwood JL, McKinney ML (2001) Biotic homogenization: a sequential and selective process. In: Lockwood JL, McKinney ML (eds) Biotic Homogenization. Kluwer Academic/Plenum Publishers, New York, pp 1-17

Lougheed VL, McIntosh MD, Parker CA, Stevenson JR (2008) Wetland degradation leads to homogenization of the biota at local and landscape scales. Freshwater Biology 53:24022413

Magurran AE (2004) Measuring Biological Diversity. Blackwell Publishing, Oxford

Magurran AE, McGill BJ (2011) Biological Diversity: Frontiers in Measurement and Assessment. Oxford University Press, New York

Margoluis R, Stem S, Salafsky N, Brown M (2009) Using conceptual models as a planning and evaluation tool in conservation. Evaluation and Prgram Planning 32:138-147

McCabe DJ, Gotelli NJ (2000) Effects of disturbance frequency, intensity, and area on assemblages of stream macroinvertebrates. Oecologia 124:270-279

Mérő TO, Žuljević A, Varga K, Bocz R, Lengyel S (2014) Effect of reed burning and precipitation on the breeding success of Great Reed Warbler, Acrocephalus arundinaceus, on a mining pond. Turkish Journal of Zoology 38:622-630

Moga CI, Öllerer K, Hartel T (2010) The effect of reed burning on the habitat occupancy of passerine species. North-Western Journal of Zoology 6:90-94

Neto JM (2006) Nest-site selection and predation in Savi's Warblers Locustella luscinioides. Bird Study 53:171-176

Nummi P, Paasivaara A, Suhonen S, Pöysa H (2013) Wetland use by brood-rearing female ducks in a boreal forest landscape: the importance of food and habitat. Ibis 155:68-79

Pan X (2013) Fundamental equations for species-area theory. Scientific Reports 3:1334. doi:10.1038/srep01334

Paracuellos M, Tellería JL (2004) Factors affecting the distribution of a waterbird community: the role of habitat configuration and bird abundance. Waterbirds 27:446-453

Perrins C, Cramp S (1998) The Birds of the Western Palearctic. CD-ROM edn. Oxford University Press, Oxford

Poulin B, Lefebvre G (2002) Effect of winter cutting on the passerine breeding bird assemblage in French Mediterranean reedbeds. Biodiversity and Conservation 11:1567-1581

Poulin B, Lefebvre G, Mauchamp A (2002) Habitat requirement of passerines and reedbed management in southern France. Biological Conservation 107:315-325 
Pöysa H, Vaananen V-M (2014) Drivers of breeding numbers in a long-distance migrant, the Garganey (Anas querquedula): effects of climate and hunting pressure. Journal of Ornithology 155:679-687

Rácz IA, Déri E, Kisfali M, Batiz Z, Varga K, Szabó G, Lengyel S (2013) Early changes of orthopteran assemblages after grassland restoration: a comparison of space-for-time substitution versus repeated measures monitoring. Biodiversity and Conservation 22:2321-2335

Redolfi De Zan L, Battisti C, Carpaneto GM (2010) Effect of spring water stress induced by fishery farming on two duck species Anas platyrhynchos L. and Anas crecca L. in a Mediterranean wetland. Pollish Journal of Ecology 58:599-604

Salafsky N, Butchart SHM, Salzer D, Stattersfield AJ, Neugarten R, Hilton-Taylor C, Collen B, Master LL, O'Connor S, Wilkie D (2009) Pragmatism and practice in classifying threats: reply to Balmford et al. Conservation Biology 23:488-493

Salafsky N, Salzer D, Stattersfield AJ, Hilton-Taylor C, Neugarten R, Butchart SHM, Collen B, Cox N, Master LL, O'Connor S, Wilkie D (2008) Standard lexicon for biodiversity conservation: unified classification of threats and actions. Conservation Biology 22:897911

Schmidt MH, Lefebvre G, Poulin B, Tscharntke T (2005) Reed cutting affects arthropod communities, potentially reducing food for passerine birds. Biological Conservation 121:157-166

Schweiger EW, Leibowitz SG, Hyman JB, Foster WE, Downing MC (2002) Synoptic assessment of wetland function: a planning tool for protection of wetland species biodiversity. Biodiversity and Conservation 11:379-406

Schwilk DW, Keeley JE, Bond WJ (1997) The intermediate disturbance hypothesis does not explain fire and diversity pattern in fynbos. Biodiversity and Conservation 11:379-406

Tanneberger F, Tegetmeyer C, Dylawerski M, Flade M, Joosten H (2009) Commercially cut reed as a new and sustainable habitat for the globally threatened Aquatic Warbler. Biodiversity and Conservation 18:1475-1489

Vadász C, Német Á, Biró C, Csörgö T (2008) The effect of reed cutting on the abundance and diversity of breeding passerines. Acta Zoologica Academiae Scientiarum Hungaricae 54:177-188

Valkama E, Lyytinen S, Koricheva J (2008) The impact of reed management on wildlife: a metaanalytical review of European studies. Biological Conservation 141:364-374

van der Toorn J, Mook JH (1982) The influence of environmental factors and management on stands of Phragmites australis. II. Effects of burning, frost and insect damage on shoot density and shoot size. Journal of Applied Ecology 19:477-499

van Deursen EJM, Drost HJ (1990) Defoliation and treading by cattle of reed Phragmites australis. Journal of Applied Ecology 27:284-297

Vásárhelyi T (1995) Nature conservational aspects of reedbed management. In: Vásárhelyi T (ed) Nádasok élővilága (Biota of Reedbeds). Hungarian Natural History Museum, Budapest,

Vinton MA, Hartnett DC, Finck EJ, Briggs JM (1993) Interactive effects of fire, bison (Bison bison) grazing, and plant community composition in tallgrass prairie. American Midland Naturalist 129:10-18 
Vulink JT, Drost HJ, Jans L (2000) The influence of different grazing regimes on Phragmites and shrub vegetation in the well-drained zone of a eutrophic wetland. Applied Vegetation Science 3:73-80

Wagner KI, Gallagher SK, Hayes M, Lawrence BA, Zedler JB (2008) Wetland restoration in the new millennium: do research efforts match opportunities? Restoration Ecology 16 (3):367-372. doi:10.1111/j.1526-100X.2008.00433.x

Wheeler BD, Shaw SC, Fojt J, Robertson RA (1995) Restoration of Temperate Wetlands. John Wiley \& Sons, New York

Wiens JA (1997) The emerging role of patchiness in conservation biology. In: Pickett STA, Ostfeld RS, Shachak M, Likens GE (eds) The Ecological Basis for Conservation: Heterogeneity, Ecosystems, and Biodiversity. Chapman \& Hall, New York, pp 93-107

Zacchei D, Battisti C, Carpaneto GM (2011) Contrasting effects of water stress on wetlandobligated birds in a semi-natural Mediterranean wetland. Lake and Reservoir Management 16:281-286 


\section{Tables}

643

644 Table 1. An overview of treatments in marsh habitat patches and the terminology used in this 645 646 study. Grazing was conducted in the SW part of the marsh on 200 ha between late April and late November every year between 2006 and 2010.

\begin{tabular}{lll}
\hline \multicolumn{1}{c}{ Fire management } & \multicolumn{2}{c}{ Grazing management } \\
\hline \multicolumn{1}{c}{ Burned in } & \multicolumn{1}{c}{ Grazed } & \multicolumn{1}{c}{ Non-grazed } \\
\hline 2007 & Grazed, old-burned & Non-grazed, old-burned \\
2009 & Grazed, newly-burned & - \\
Both years & Grazed, twice-burned & - \\
Never & Grazed, unburned (burning control) & $\begin{array}{l}\text { Non-grazed, unburned (overall } \\
\text { control) }\end{array}$ \\
\hline
\end{tabular}

647

648 
649 Table 2. Results of general linear models testing the effects of management, reed properties and 650 water depth on variables describing the marsh bird community. Models shown were obtained by 651 backward stepwise removal (function 'step' in R) of effects not improving model fit from full 652 models specified after a model selection procedure. Significant effects are in Bold.

\begin{tabular}{|c|c|c|c|c|}
\hline Response variable & Predictors & Coefficient \pm S.E. & $F\left(d f_{1}, d f_{2}\right)$ & $\mathbf{p}$ \\
\hline \multirow[t]{2}{*}{ Species richness } & Reed complexity $(\mathrm{CV})^{\mathrm{a}}$ & $1.87 \pm 1.032$ & $3.853(1,27)$ & 0.060 \\
\hline & Proportion of reed cut & $-2.31 \pm 1.430$ & $2.608(1,27)$ & 0.118 \\
\hline \multirow[t]{3}{*}{ Abundance } & Reed cover & $-52.19 \pm 24.781$ & $4.451(1,26)$ & 0.045 \\
\hline & Proportion of reed cut & $-21.24 \pm 10.849$ & $3.225(1,26)$ & 0.084 \\
\hline & Water depth & $-0.60 \pm 0.291$ & $4.336(1,26)$ & 0.047 \\
\hline \multirow[t]{4}{*}{ Shannon diversity } & Management & $-0.47 \pm 0.184$ & $3.324(5,21)$ & 0.023 \\
\hline & Reed complexity $(\mathrm{CV})^{\mathrm{a}}$ & $0.19 \pm 0.140$ & $2.118(1,21)$ & 0.160 \\
\hline & Proportion of reed cut & $-0.28 \pm 0.223$ & $2.398(1,21)$ & 0.136 \\
\hline & Water depth & $0.01 \pm 0.005$ & $6.137(1,21)$ & 0.022 \\
\hline \multirow[t]{2}{*}{ Simpson diversity } & Management & $0.16 \pm 0.051$ & $5.317(5,23)$ & 0.002 \\
\hline & Water depth & $-0.00 \pm 0.001$ & $8.138(1,23)$ & 0.009 \\
\hline \multirow[t]{2}{*}{ Evenness } & Management & $-0.16 \pm 0.054$ & $5.347(5,23)$ & 0.002 \\
\hline & Water depth & $0.00 \pm 0.001$ & $7.500(1,23)$ & 0.012 \\
\hline
\end{tabular}




\section{Figure legends}

657

658 Figure 1. Aerial photograph of Fekete-rét marsh (in 2005), with location of management actions.

659 Source of photograph: Institute of Geodesy, Cartography and Remote Sensing, Budapest, 660 Hungary.

661

662 Figure 2. Mean \pm S.E. community parameters in management treatment levels. Groups not 663 sharing lowercase letters are significantly different (Tukey’s HSD test, $\mathrm{p}<0.05$ ).

664

665 Figure 3. Mean \pm S.E. species richness and abundance of the five main functional groups in 666 management treatment levels. Groups not sharing lowercase letters are significantly different 667 (Tukey's HSD test, $\mathrm{p}<0.05$ ).

668

669 Figure 4. Mean \pm S.E. proportion of old reed in management treatment levels.

670

671 


\section{$672 \quad$ Figures}

673

$674 \quad$ Figure 1

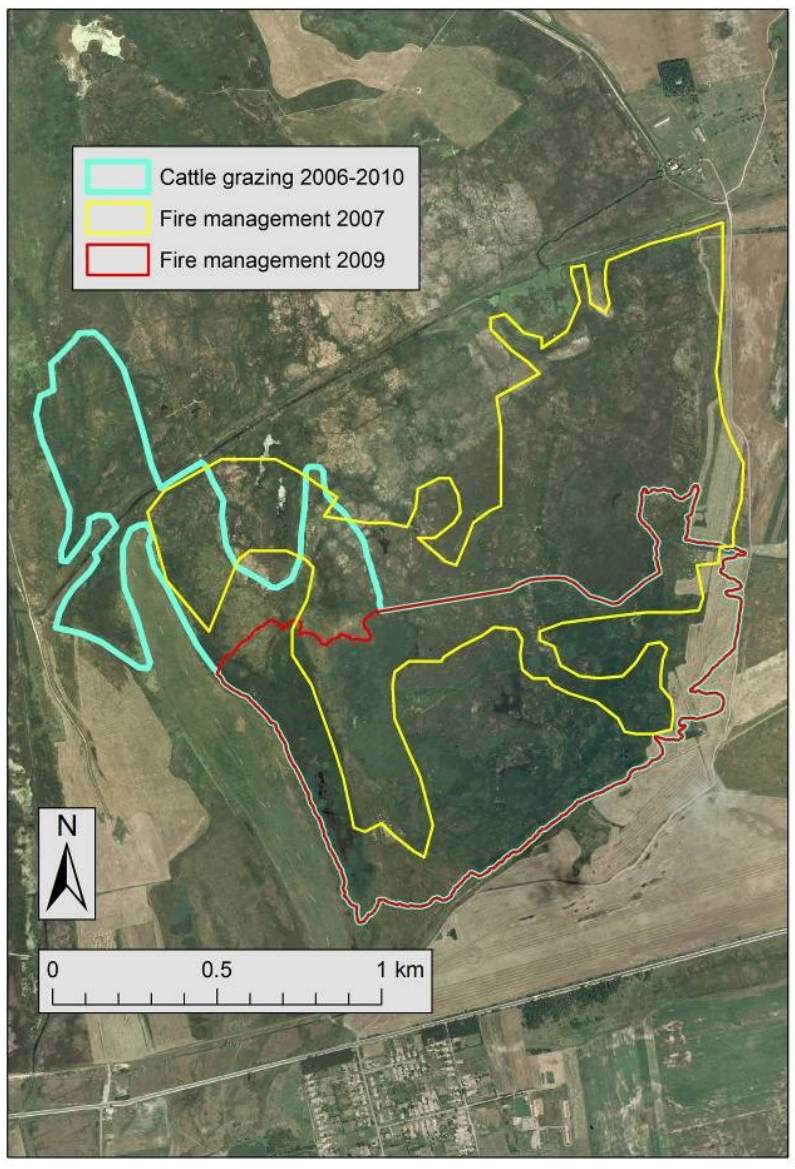

675

676

677 
Figure 2
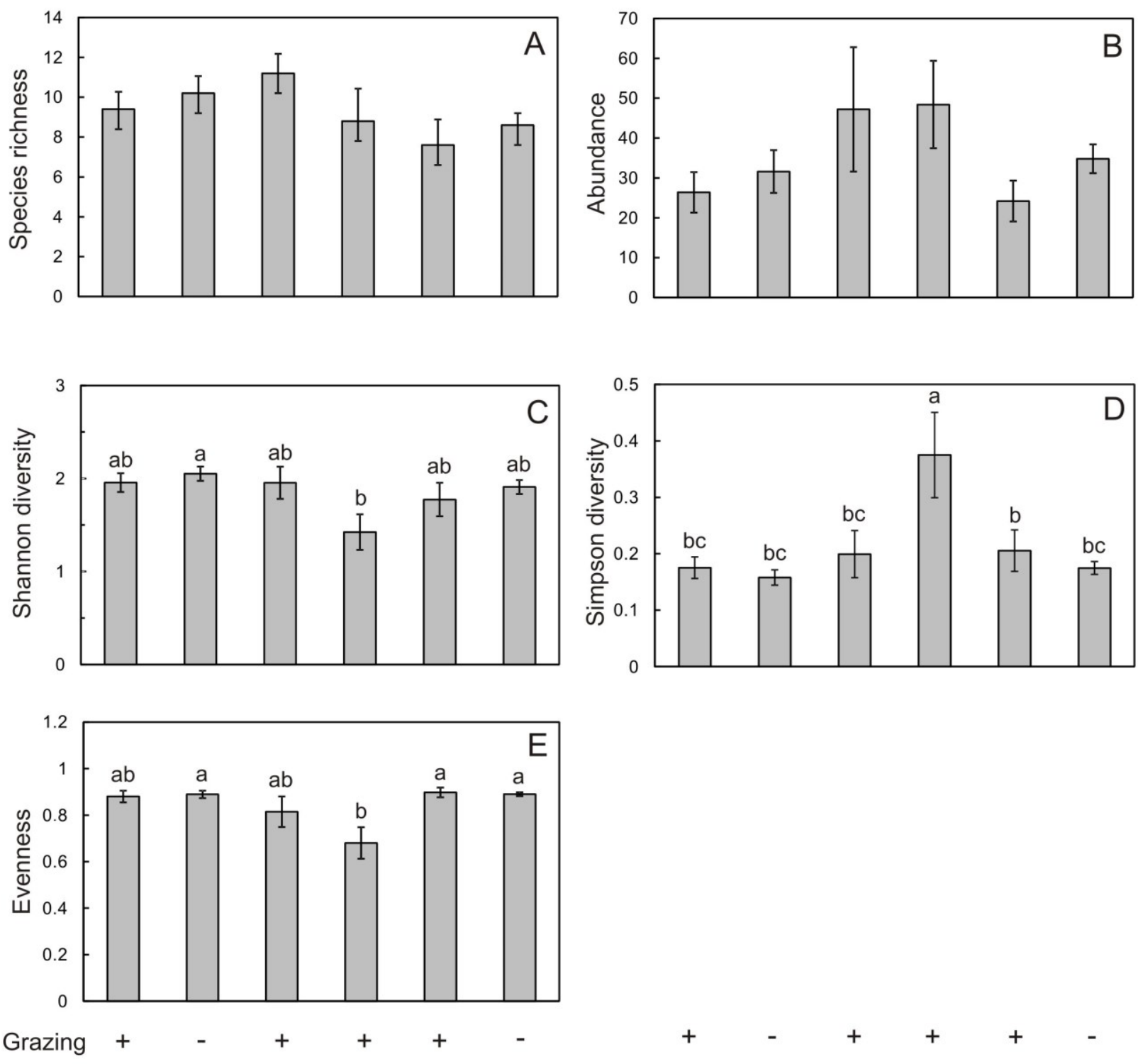
Figure 3

Species richness
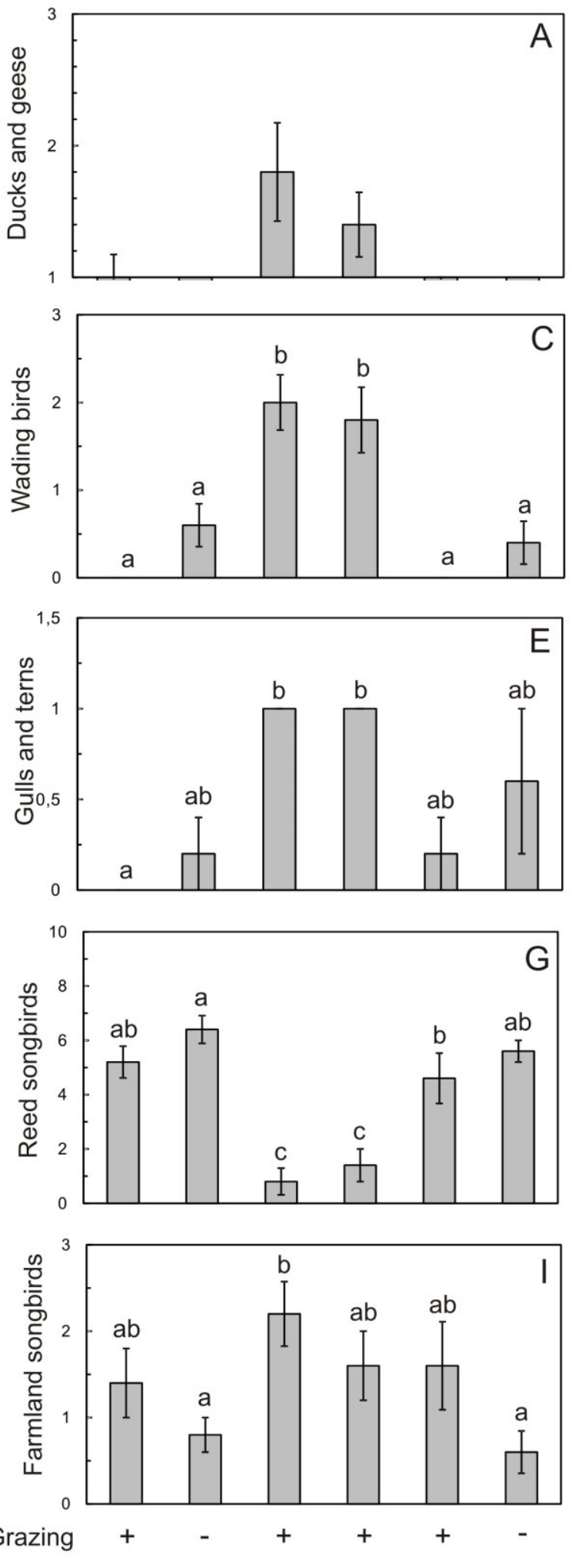

683
Abundance
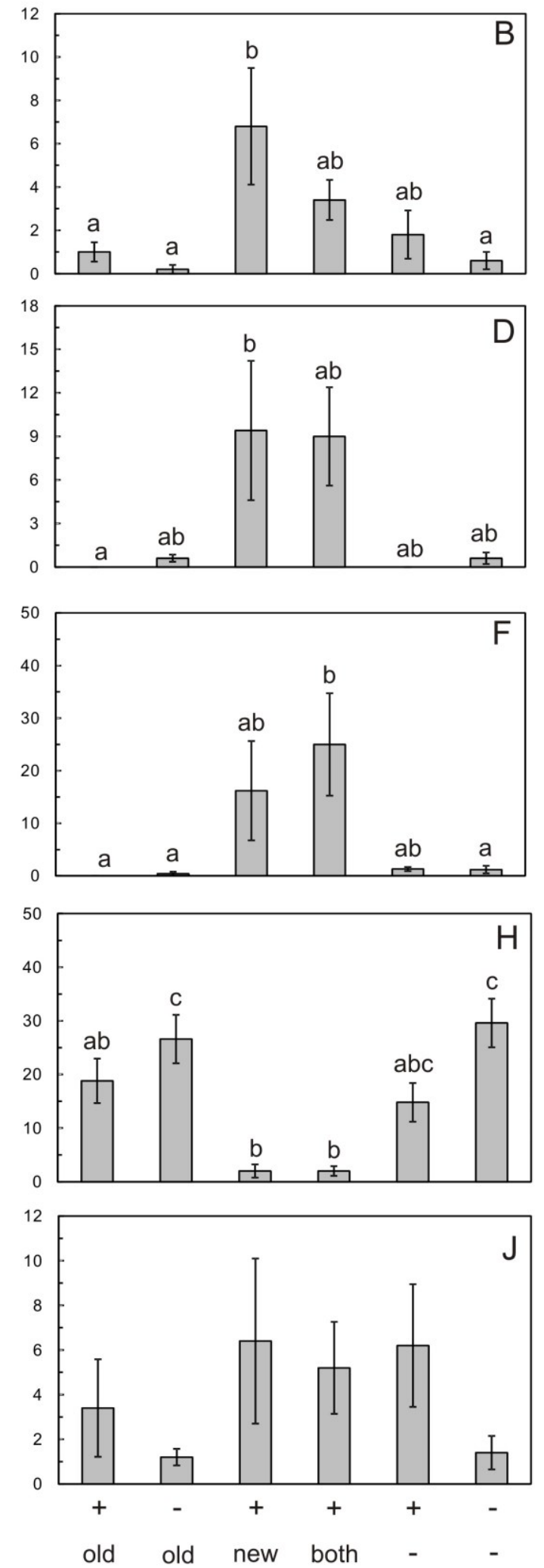
684 Figure 4.

685

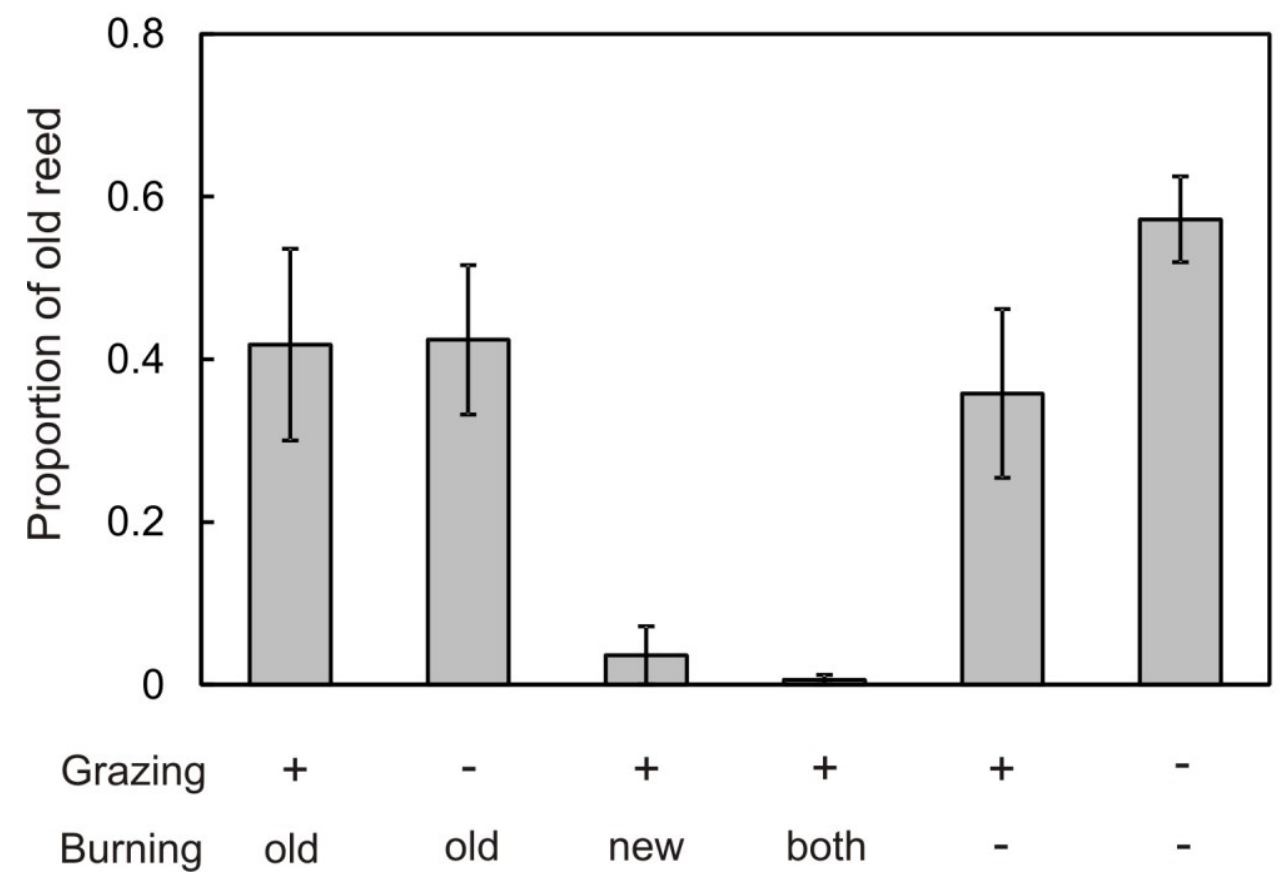

